\title{
SUSTAINABLE LAND DEVELOPMENT IN AN URBAN CONTEXT
}

\author{
Tom Kauko, Assoc. Prof. \\ Department of Geography \\ Norwegian University of Science and Technology - NTNU, Norway \\ e-mail: tom.kauko@yahoo.co.uk
}

Nikolai Siniak, Assoc. Prof.

Department of production Organization and Real Estate Economy, Belarusian State Technological

University, Belarus

e-mail:siniakn@mail.ru

Sabina Źróbek, Prof.

Faculty of Geodesy, Geospatial and Civil Engineering

University of Warmia and Mazury in Olsztyn

e-mail: zrobek@uwm.edu.pl

\begin{abstract}
It can be argued that sustainable urban land development depends on the long-term viability and management success of local economic development. It can be further argued that here, economic sustainability is the key. This would furthermore signify a paradigm change to long-term administrative behavior (via an institutional approach), long-term market behavior (heterodox economics approach), and human behavior in actors' consumption and location choices (behavioral approach). This article examines two criteria within this discourse: innovativeness and social cohesion. In doing so, it proposes a framework for empirical analysis where it is suggested that western, postsocialist and low developed cases choose different strategies due to their different starting points.
\end{abstract}

Key words: economic sustainability, land development, sustainable development, urban sustainability.

JEL Classification: R00, R14, R38, R52, R58.

Citation: Kauko T., Siniak N., Źróbek S., 2015, Sustainable Land Development in an Urban Context, Real Estate Management and Valuation, Vol. 23, No. 3 pp. 110-119.

DOI: $10.1515 /$ remav-2015-0030.

\section{Introduction}

Some might argue that not enough real estate analysis has been carried out since the beginning of the global financial and economic crisis in 2008, given the central role played by bursting real estate market bubbles. At the time of writing, this crisis is not yet over - if anything it is only worsening, due to the worsening of several particular crises, notably the financial problems of certain National economies within the EU. Even if the current global crisis is only temporary, we could argue that the damage done by the crisis has long-lasting consequences for producers, consumers and intermediators living off of real estate, building and land development industries. There will ostensibly be fundamental changes in attitudes, demand and supply structures, markets, regulative measures and policy initiatives, and most certainly, paths taken by technological progress (e.g. Joss 2011). What is, then, the correct course of action? Besides the financial-economic considerations, while pivotal in themselves, it is rather difficult not to see any such changes as integrated onto the broader sustainable 
development discourse, which, in one way or another, focuses on the need to improve the usage of the Earth's resources - natural, material and human alike. And for this we need sustainably legitimate and financially sound behavioral models on all levels, ranging from the individual consumer and citizen, or small firm, via local community and governance interests, to corporate strategies and government agendas.

This article examines urban sustainability goals with respect to cohesion and innovativeness of land development decisions. These two criteria have been chosen for investigation because the immediate effects of physical development often have broader economic and social consequences, and in this picture, both backwardness and inequality remain recurring problems to combat. Here, the definition of urban land development covers both new developments and existing neighborhoods subject to revitalization. Our research problem concerns environmental, economic, social and cultural sustainability assessment of land development within housing, office and urban regeneration uses. Taking such a normative stance, a number of criteria of sustainability will be operationalized into an empirically testable framework split into three city- and country-specific cases representing the circumstances of Western, post-socialist and developing countries.

\section{A twelve point program for urban sustainability}

While the concept of sustainability might have been already in use in the 1960s, the first serious academic debates about the definitions of how sustainability is to be approached emerged in the 1980s. Despite improvements much of this debating is still present (cf. STØA 2009, MANZI et al. 2010 a, b, COLANTONIO and DIXON 2011, TALEN 2011). Several points of disagreement still prevail; while most of them are beyond the purposes of this study, the relative neglect of the spatial element of the sustainability concept interests us greatly. According to ZUINDEAU (2006), the problem behind successful bottom-up management of cities and regions lies in cooperation across adjacent territories. Here especially vital is the cooperation among private sector actors in adjacent or adjoining municipalities. Other research leads to the conclusion that effective spatial planning requires wide economic and social knowledge-sharing, concerning both city and the smallest administration units located in the neighborhood; these new challenges in managing cities and their suburban areas also require modernization of university education programs for future spatial managers (ŹRÓBEKRÓŻAŃSKA et al.2014).

Drawing on the spatial (rather than the inter-general) approach in a rather ad hoc way, twelve broad issues revolving around the sustainability of urban land use and urban area development were selected. These are listed below, starting from the most localized to the widest scale, based on various literature positions (urban sustainability, sustainable real estate, in particular), as well as anecdotal evidence. For the latter sources, the matters are of two types: the first, the presented uncritical opinions of the sustainability actors themselves, even if such are often to be dismissed as mere "window-dressing" - it is our task as researchers to filter this information; the second - reports of policy-oriented studies carried out by supranational bodies who, while arguably not completely objective either, at least employ commonly accepted research methods. The spatial scale is expanded here as listed below: items 1 to 3 are at the utmost micro-level pertaining to the building; items 4 to 6 are meant to cover on-site development; items 7 to 10 operate at the neighborhood level; items 11 to 12 concern a whole city/metropolitan region. We also note that the scales overlap, depending on the exact definitions of spatial units applied: items 7 to 10 could just as well cover a whole urban area.

1. Energy efficiency in buildings (during their life cycles).

2. Use of renewable energy in buildings (during their life cycles).

3. Pollution control in buildings (during their life cycles).

4. The quality of property products.

5. The affordability of property products in relation to social diversity arguments.

6. The diversity of property products.

7. The optimal density for a block or neighborhood.

8. Public transportation availability.

9. Traffic pollution.

10.Social cohesion in the neighborhood or city.

11. Communicativeness in local or regional planning (governance transparency) 
12.Innovativeness of the region (economic sustainability, including financial transparency of corporations, and favoring local products and labor).

In practice, many of the twelve points listed above are interlinked. The EU sustainability strategy for example focuses on climate change and clean energy, sustainable transport, consumption and production, conservation and management of natural resources, public health, social inclusion, demography and migration, and global poverty. In the USA, in turn, sustainability is defined in the context of the "environmental justice agenda" according to which marginal and poor groups should not disproportionately bear the costs of public or private activities or policies. While precise causal relationships are uncertain, policies to ameliorate the negative environmental and socio-economic externalities are necessary to ensure sustainable communities (MANZI et al. 2010a, b).

Because of space constraints, only a few of the effects can be focused on here. Hereafter, items 10 and 12 are chosen for further scrutiny (due to reasons explained in the introductory section). Focus on only social cohesion and innovativeness is justified in the sense of summarizing many of the other items, notably items 6 and 7 .

\subsection{Social cohesion in a neighborhood or city}

In order to put the social cohesion discussion into wider context we refer to social sustainability - even though the definition of this concept is far broader than the definition of social cohesion (it is, in fact, inseparable in relation to environmental and economic dimensions). GACZEK (2003) has argued that the way land and property is managed influences the quality of life of its inhabitants. Social sustainability may be defined in terms of social equity, access to resources, participation, social capital, human rights and exclusion (MANZI et al., 2010A, B). According to MANZI and colleagues (2010b) the issue is whether governments are competent to steer partnerships and networks - and well-placed to incorporate a wider range of stakeholders in the delivery of urban processes (pp. 10-15). These authors furthermore maintain that social sustainability is an important guiding principle for the direction of policies and the environment, despite conceptual flaws and practical difficulties. MANZI and colleagues (2010a) conclude that social sustainability requires investment and not only plans.

\subsection{Innovativeness of the region}

Learning new procedures and management principles is often argued to be the key to urban sustainability (CAMPBELL 2000, EDÉN et al. 2000). In particular, this argument involves the economic dimension which means the way work, saving and reinvestment are stimulated by incentives. ${ }^{1}$ According to BRYSON and LOMBARDI (2009), maximizing short-term profits in residential development projects in cities leads to unsustainable development in the long run. Conversely, the longevity of the project - an important precondition for sustainability - can be enhanced if normal profits are reaped and the remaining margins are reinvested wisely, for example, in bus stops, green features of the buildings and other areas, or in other innovations that improve the social and environmental sustainability of the project. Getting private developers interested in financing non-economic elements, however, requires good governance and designing apt institutions for responsible investments. However, it can be argued that only after economic solidity is achieved is investment in social cohesion affordable. This mode of analysis is consistent with the overall approach to urban sustainability known as ecological modernization.

\section{Context dependent sustainable urban property management functions}

The general strategic discussions above highlighted the justification of different goals for social cohesion and economic innovativeness within an urban land development context. In this vein, some specific examples of institutional and geographic circumstances are presented next. The discussion proceeds in three parts depending on whether the issues primarily concern western, post-socialist or low developed countries.

\footnotetext{
1 Economic sustainability is, however, not a new concept. Already in $17^{\text {th }}$ century Europe, a distinction could be made between the sustainable Spanish kingdom and the unsustainable Polish one. In the former, investments were made in public services for the people; for example, the first street lights were developed. In the latter kingdom, the revenues were just consumed by an elite group of approximately five percent of the population, whereas the rest of the population was starving. We could make similar notions of how unsustainable regimes communism produced, and in contemporary times, about the EU banking crisis which is also "disincentivizing" for the ordinary taxpayer.
} 


\subsection{Western circumstances}

Currently several types of innovative schemes that combine the best capabilities of both private and public actors are in use in Continental Europe. In Germany and Austria evidence shows that cities have the means to become sustainable naturally - thus through "intrinsic logic" of local actors rather than in response to policies or directives (FENDT 2010, PESSINA and SCAVUZZO 2010). The Smiley West housing scheme in suburban Karlsruhe, Germany, is an actively touted sustainable property development that was established and is completely run by its residents. These are all owneroccupiers (and as a socio-cultural group can ostensibly be characterized as representing the "liberal younger middle class"). This development concept is built on a spontaneous trust and community lifestyle, and with a belief in further uptake of potentially sustainability enhancing innovative ideas.

To show a different development strategy, the Red-for-Green mechanism increasingly used in the Netherlands relies on more top-down management. When discussing economic sustainability, this land development practice is a case in point: unprofitable parts of spatial developments, such as landscape and hazards management, as well as social arrangements are financed from an ear-marked value capturing of the profitable parts of a new urban development project (GOETGELUK et al. 2005, DE WOLFF and SPAANS 2010). This case exemplifies the flexible policy frameworks in this country. Here the shares of duties and benefits among the participants in PPPs are defined by contracts according to the principles of New Public Management.

In contrast to the Continental tradition, the UK and Nordic countries exemplify somewhat different circumstances, as their sustainability policies rely heavily on regulation. Nonetheless, in the UK, since the late nineties, adaptable developers have emerged. For example, Igloo Development Corporation accepts the existence of different characters of a place and thereby recognizes different valuations for different groups of people. In the Nordic countries, in turn, a lesser urgency to implement sustainability agendas has to do with the lack of population pressure compared with other European circumstances. While differences in practice and research are also huge between these countries (EDÉN et al. 2000)2 , they share the tendency of conflicts arising between public and private actors. We therefore consider the positive sustainability evaluation of these countries a common misconception. ${ }^{3}$

Another misconception (in the opposite direction) concerns the USA, as in some circles, liberal markets and sustainability agendas are seen as incompatible goals. The evidence speaks for itself here: few countries are as innovative in this regard as the USA. Examples include New Urbanist developers who actively pursue sustainability related motivations (see DEITRICK and ELLIS, 2004; GRANT, 2009; LARSEN, 2005; MORROW-JONES, IRWIN and ROE, 2004; SONG and KNAAP, 2003), and sustainable growth management such as Florida's Optional Sector Planning (OSP) approach (CHAPIN 2012). Of other countries with promising track records in sustainability evaluations we can name at least Canada, Australia and New Zealand. The practices in these countries are, however, not immune to the usual problems, such as weak political commitments and market pressures, as Grant (2009), who discusses the Canadian experiences with the sustainable planning of suburbs, concludes.

Optimistically considered, all these examples connect to cohesion and innovativeness. However, if the issue concerns the validity of generalizing across regions of different levels of development, we have to realize that these models are typically designed for and established in the circumstances of "the western world". For example, COLANTONIO and DiXON (2011, pp. 215-216) admit to being Eurocentric when they assess such transferability of socially sustainable urban regeneration models. We can, nevertheless, already draw an interim conclusion based on the experiences from "developed" or "western" urban circumstances: the most positive evaluations of sustainability are for cases where the private sector drives the development. The key here is the ability of private actors to constantly, through spontaneous bottom-up processes, seek new opportunities to generate economic surpluses from which social and environmental amenities, in principle, can be financed. However, the policy

\footnotetext{
2 Especially in Norway, the system of spatial planning and land use regulation is rather rigid. In this country, the municipality still has a negative, regulating attitude to new building of homes by private parties, even if some cooperation does take place.

${ }^{3}$ To be fair: some innovative tools have been developed in Sweden, such as the "urban landscape" concept in plans meant to secure urban biodiversity (ERLANDER et al. 2005).
} 
level is not to be forgotten either as total sustainability also requires innovative incentive schemes of top-down character to be combined with.

\subsection{The post-socialist context}

The changes taking place in Central and Eastern European (CEE) Countries were dominated by the transition to a market economy. This process involved many and varied decisions related to space, space management and the administration system. In Poland, for instance, in 1990, the public administration reform made self-government authorities in individual provinces (voivodeships) responsible for their social and economic development. Local authorities of self-governing communes (gmina) and cities on the laws of the district (poviat) decide about their development and formulate the principles of spatial management. In 1991, the Parliament of Poland approved the "Ecological Policy of Poland". According to the law concerning the protection and formation of the environment, schools of all levels are obliged to include ecological aspects in their educational activities. The new Law of Spatial Management from 1994 (and then from 2003) admits the sustainable development principle as the basis for activities connected with all aspects of land management. In order to implement the assumptions of ecodevelopment, it was necessary to fulfill many demands. Covering the need for data collecting and processing in a better and more economical way is one of them. The second was money.

The main mistake made by countries of CEE after the transition was the overambitious reliance on local responsibility instead of any state involvement in sustainable development (VÁSÁRHELY, 2006). While the lack of knowhow could be alleviated by educating professionals, the lack of finances became an impossible problem to overcome. When the issue was about how to revert the "tragedy of the commons", Gulácsy and colleagues (2006) argue that sustainability and environmental policy have failed to pay attention to decision-making pursued by individuals. This failure is notable even when dealing with circumstances of relatively developed countries, such as the Czech Republic (MEZř̃ICKÝ 2006).

Gross and Źróbek (2013) investigated public real estate management systems in four post-socialist countries: Lithuania, Latvia ,Poland and Ukraine. In their opinion, public-private partnerships are occasionally used in these countries. More and more such projects, however, are being realized from year to year, and only Ukraine does not use these partnerships. WOJEWNIK-FILPKOWSKA (2012) shows the dimensions of public private arrangements and their application in the process of urban regeneration, exemplified by railway area regeneration in the Polish town of Sopot. Despite the many positive aspects of this form of cooperation between the public and private sector, existing barriers prevent the full utilization of potential of PPPs. A low level of knowledge on the subject, the lack of available practices, and the lack of the dissemination of the best practices are often mentioned as important factors restricting the development of public-private partnerships in Poland.

VAISHAR and GREEN-WOOTTEN (2006) purport the regional level as the most feasible level of action, and add that the sustainability of a given region ought to be evaluated by interdisciplinary research. The focus of much of such research is in the quantitative and qualitative aspects of various conflicts, and the causes behind their existence. For example, ŹRÓBEK and ZACHAŚ (2005) analyzed conflicts that arise in Poland at the stage of working out local spatial management plans and conflicts that are reported by the inhabitants to the municipal police. One of the causes for the conflicts rooted in the problems of the everyday city life was the lack of the sufficient analysis of social needs (parking against the law; illegal disposal of waste and rubble). Unfortunately, to some extent, "Eastern European miserablist literature" established in the mid nineties has, due to its stereotypical descriptions, much undermined constructive attempts to evaluate the real circumstances where decision-makers have to act amid unfavorable institutional and cultural legacies and harsh economic realities (LADÁNYI 1993, HEGEDÜS et al. 1994, KOVÁCs 1998, SILHANKOVA et al. 2011).

Here, recent evidence from two Hungarian cities (Budapest and Szeged) underscores some of the argumentation and further research questions in this context. The results indicate that, in Budapest, cultural heritage plays a role insofar as old well-maintained buildings and blocks function as a positive impact on the daily lives of locals, and is also a "magnet" for those coming from further afield. In Szeged, in contrast, the green environment, mixed use, moderate density, walkability and favorable conditions for cyclists, public transport and other rather unquestionable features of urban sustainability were identifiable. These findings suggest that a relatively well-developing regional city 
such as Szeged might be more successful as a "sustainable city" than a capital city such as Budapest (KAUKO 2013).

The corollary for this group of countries is to examine the economic dimension of sustainability, even when we move away from typically western circumstances. Indeed a market development trend remains unsustainable until a given real estate sector, in a given place, becomes marketable for individual owners/renters, project developers and institutional investors. The investment of the private sector and industry perspective cannot be played down at the expense of other issues, although government regulation, public policy and planning issues are the keys to successful postsocialist urban transitions. In this model a "mature market" needs to be set up first, which requires the government to establish apt supporting institutions and policies. After that, sales of new developments and renovated stocks are likely to generate profits that then need to be directed to longterm investment in affordable homes, landscaping and other infrastructure.

\subsection{Underdeveloped regions}

As billions of poor are excluded from access to productive resources, it is justified to speak about a social bubble based on poverty and inequity even if we disregard the financial-economic aspects. In a time when humankind faces environmental dangers and shortages of resources, the top $20^{\text {th }}$ percentile of the world's population by income consumes 60 times more than the lowest $20^{\text {th }}$ percentile. In principle, these problems could be mitigated, but one can note that, in the aftermath of the financial collapse, the leaders of the world continued to support banks and to promote unsustainable consumption instead of using the opportunity to allocate a much larger share of investments to green investments. However, it can also be noted that even economically less fortunate consumers can be encouraged to behave more economically, socially and environmentally sustainably, as they too are stakeholders when it comes to sustainable development. For this to happen, however, the current practice of subsidizing the developing regions needs to be replaced with a practice that triggers innovation at the grass-root level (MUNASINGHE 2010). ${ }^{4}$

Joint Nobel Peace Prize winner Mohan Munasinghe (keynote speech 2012) sees the problem in our rhetoric: even if c. $80 \%$ of global consumption is done by the rich, we are at the same promising prosperity to the poor despite having already reached our global carrying capacity. He suggests a two-way solution to this problem: (1) governments push businesses towards the right direction; (2) the encouragement of bottom-up processes, that is to say, spontaneous activity (reducing energy, carbon neutrality, etc.). Munasinghe's "Sustainomics" conceptual framework as such prescribes the remedy to how poor countries can develop sustainably: by creating economic livelihoods instead of giving handouts to the poorest. First, a few sustainable producers need to be created; then a few sustainable consumers should be created as their counterpart; and finally, these groups should be brought together in a sustainable market. Establishing bottom-up business activity that does not expect financial handout policies is at the core of this approach. ${ }^{5}$

Unfortunately much of the current discourse deals with these issues in a rather black and white manner that hinders the application of the constructive development approach suggested above. To give an example of such an unconstructive approach, Potter and colleagues (2012) sees "modernity" and neo-liberalism at its particular contemporary form as the culprit for every problematic development manifestation in the Global South. At this stage, however, after taking stock of the problems of the post-socialist context of urban sustainability documented above, one is entitled to be sceptical towards any merits of a purely political view. What about the incompetent and corrupt economic and political leaders in these countries? And what about their inability to develop financial mechanisms and functional logistics systems that would be essential for a truly entrepreneurial local culture to take off?

Moreover, Potter and colleagues consider sustainable development policy, in generally sweeping terms, incoherent and inefficient. As they put it, "the plight of the Global South's poor's majority does

\footnotetext{
4 Here is also reason to refer to Berman and colleagues (2013), who present new research findings against "injecting lots of money into conflict zones" in the face of their assumed encouragement of corruption and violence.

5 Cheryl Hicks (keynote speech, 2012) is in agreement that the economic growth of poor countries might be possible. Here, the context matters; we need to identify the hotspots of consumption for different markets. It is a two-level development: first, to design policies, and next, to change our own values.
} 
not feature prominently among the global goals of contemporary sustainable development," (p. 108). This highlights the limited ability of the neo-Marxist approach to deal with the challenges of a modern sustainability-enhancing agenda. In reality the sustainability of capitalism depends on the education of consumers and professionals, as well as on the implementation of smart regulations and economic incentives. Thus a zero sum game with an inbuilt destructive automata of capitalism in the sense postulated by the neo-Marxists is clearly an invalid conclusion. This is obviously not to say that neoliberal government policies cannot be criticized, quite to the contrary; the proposition is rather to replace the outmoded and unfruitful antagonism between neo-Marxists and neoliberalists with a genuinely sustainable development view in relation to institutional, evolutionary, ecologic and complexity economics, together with an approach related to human behavior (FOXON et al. 2012).

\subsection{Summarizing: Towards an empirically testable framework}

Figure 1 summarizes three country-specific urban and sustainable development contexts discussed above in a typology and unified framework for further empirical analysis. The developed (or western) type of cases constitutes a convenient starting point and benchmark for the other two cases - after all, most (even if by no means all) of the discourses about sustainable development began by intellectual activity practiced by individuals and organizations representing this category of countries. On the basis of literature and best practice from these countries we can assume that, by sustaining the optimal preconditions for the market to trigger private investment activity within a favorable institutional framework, the social and cultural spheres are likely to improve in the long run (akin to the case of late Medieval Florence). On the other hand, while the same principle applies to post-socialist and LDC cases: economic surplus being the source for financing the social (and whenever possible, cultural) arenas, the need for government steering is stronger in these circumstances because of their lower levels of market maturity. For the LDC category it is also important to note that, as long as market structures are still at an early stage of development, it is important that experiences from more social agendas are used to consult economic agendas through a constant feedback process, and not only in the direction from economic to social. That is to say: developing the policy discourse through trial and error, and learning by doing. Obviously, in this iterative process experiences from both western and post-socialist contexts are of value in informing, on a case-by-case basis, how the LDC system is to be set.

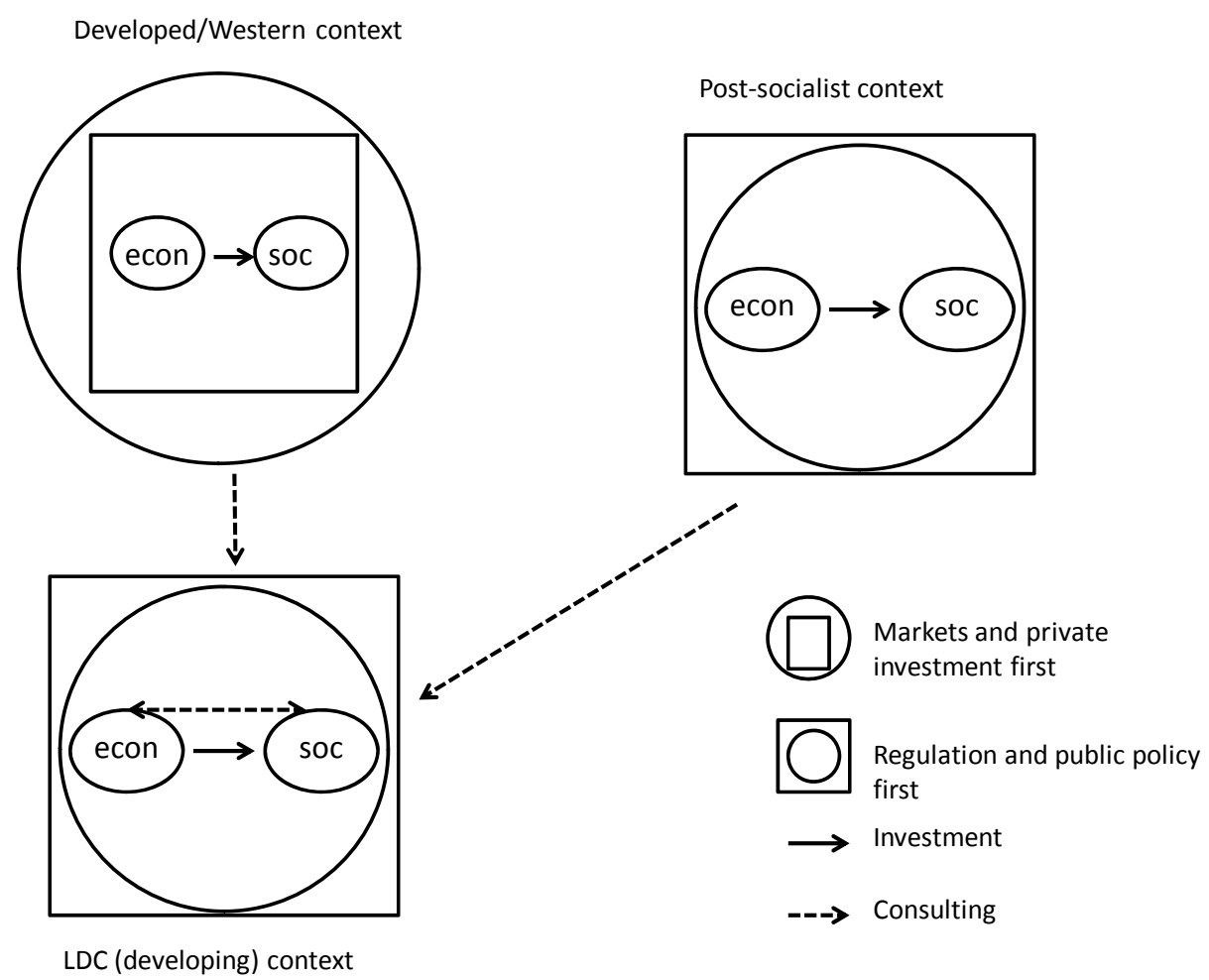

Fig. 1. Empirically testable framework for the three cases of urban development and sustainability. Source: own study. 


\section{Conclusions}

Our argumentation in this study is to be understood as an attempt to trigger serious research efforts and interdisciplinary debates around the concepts of sustainable land development and urban sustainability. We would welcome any constructive approach to evaluating sustainability in the context of urban land use and area development. Our point here is about incremental changes rather than "one grand planning vision" utilizing knowledge on how economic sustainability can generate environmental and social sustainability. Here the solution depends on if an economic long-term strategy geared towards reinvesting the profits made from developments can be set up. Apart from this, incentives and regulations set on national, regional and local levels, as well as capacity building through participatory procedures are also required to produce patterns of sustainable urban development.

In our view steering investments onto a sustainable track is more important than government regulations about sustainability. Besides the obvious fact that regulations become outmoded quickly, the private sector in general has, through experience, a better capability for dealing with risks and improving quality than the public sector. Eventually even government structures will adapt to sustainability criteria, but the immediate aims are likely to be more of a "bottom-up" than "top-down" character6. Thus the approach we argue for is to examine how organic change (i.e. change that happens more continuously and incrementally as a result of market-based processes), as opposed to government-induced change (i.e. change that is the result of policy/political actions), can occur by convincing investors, developers and house buyers of the need to engage in sustainability enhancing strategies. The pivotal issue is, in other words, to educate real estate actors on becoming voluntary sustainability practitioners.

Here the low-developed circumstances of course pose an analytical challenge. Whereas the old development paradigm was about feeling pity and thinking of ways to help the global poor, over the last decade or so it has been about how to include them in business activity - so to look at these people from a business perspective. The rationale is to create value for the business activity of and for the people who, despite living in poverty, are able to increasingly engage in this business activity. Following Munasinghe's innovative idea of setting up the contextual frameworks and preconditions for exchange rather than continuing with financial subsides is likely to demonstrate local opportunities for economic gains. There is, however, an inherent problem to overcome; namely, to convince those trained in typical Marxist ideology, who tend to shift the blame on former colonial powers, multi-national corporations and global financial capitalism rather than on barriers resulting from institutional and cultural factors, most notably substandard logistics systems, corruption and destructive local customs and practices. ${ }^{7}$ Thus, while it can be argued that a critique of neoliberal politics is necessary, it does not mean following a neo-Marxist perspective.

Thus, we argue that successful implementation of sustainable urban land development requires, first and foremost, private investments that are channeled transparently, innovatively and with longterm goals. In addition, to support this aim some form of government involvement is also required. Economic sustainability - and by implication innovativeness - is essential for development whenever the strategy is to set up a functioning local system of market and community activity. Then, when economic sustainability is achieved, the next task becomes to channel the funds towards socially and environmentally sustainable realms. Of these two dimensions the social dimension - including issues concerning social cohesion - is the less explored one as it needs more exact definitions than those currently in use for policy evaluation (BRAMLEY et al. 2009, ALLEN and LLOYD-JONES 2010, MANZI et al. 2010a, b, COLANTONIO and DIXON 2011).

\section{References}

AlLEN J., LlOYD-JONES T., 2010, Neighbourhood Asset Management: Life Cycles and Learning for Social Sustainability [In:] Social Sustainability in Urban Areas, Ed. Manzi T., Lucas K., Lloyd-Jones T., Allen J., Earthscan, London and Washington D.C., 2010, pp. 65-82.

\footnotetext{
6 Also see Wallner et al. (1996), who argue for "islands of sustainability"- an island being "an area where sustainability is reached at a local or regional level"- being able to act as cells of favorable development.

${ }^{7}$ And this despite the fact that these countries gained independence over half a century ago!
} 
BERMAN E., FELTER J., SHAPIRO J.N., TROLAND E., 2013, Effective aid in conflict zones, http://www.voxeu.org/article/effective-aid-conflict-zones, VOX Cepr's Policy Portal, 26 May 2013, access 21.06.2013.

BRAMley G., DEMPSEY N., POWER S., BROWN C., WATKINS D., 2009, Social sustainability and urban form: evidence from five British cities, Environment and Planning A, 41, pp. 2125-2142.

BRYSON J.R., LOMBARDI R., 2009, Balancing Product and Process Sustainability against Business Profitability: Sustainability as a Competitive Strategy in the Property Development Process, Business Strategy and the Environment, 18 (2), pp. 97-107.

CAmpbell H., 2000, Sustainable Development: Can the Vision be Realized? Planning Theory \& Practice, INTERFACE, 1 (2), p. 259.

CHAPIN T., 2012, Introduction. From Growth Controls, to Comprehensive Planning, to Smart Growth: Planning's Emerging Fourth Wave, Journal of the American Planning Association, 78 (1), pp. 5-15.

COLANTONIO A., DiXON T., 2011, Urban Regeneration and Social Sustainability: Best Practice from European Cities, RICS Research, Wiley-Blackwell, Chapters 1-4 and 11.

DEITRICK S., ELLIS C., 2004, New Urbanism in the Inner City: A Case Study of Pittsburgh, Journal of the American Planning Association, 70 (4), Autumn, pp. 426-442.

DE WOlfF H., SPAANS M., 2010, The Concept of red-for-green in the Netherlands, Paper presented at the $4^{\text {th }}$ conference of the International Academic Association on Planning, Law and Property rights (PLPR), Dortmund, 10-12 February. Available online at http://www.plpr2010.tudortmund.de/_downloads/PLPR2010_Paper_De\%20Wolff\&Spaans.pdf, access 11.03.2010.

EdÉn M., FAlKheden L., MALBerT B., 2000, The Built Environment and Sustainable Development: Research Meets Practice in a Scandinavian Context, Planning Theory \& Practice, 1 (2), Interface, pp. 260-272.

ERLANDER I., LuNDGREN ALM E., MALBERT B., SANDSTRÖM U.G., 2005, Biodiversity in Urban Governance and Planning: Examples from Swedish Cities, Planning Theory \& Practice, 6 (3), pp. 283-301.

FENDT M., 2010, Facing the challenge of sustainability: Environmental policies and urban development in Mainz and Wiesbaden in comparison, EURA Conference, 24-26 September, Darmstadt, Germany.

FoxON T.J., KÖHLER J., MichiE J., OUGHTON CH., 2012, Towards a new complexity economics for sustainability, Cambridge Journal of Economics, Advance access, November 23, pp. 1-22.

GACZEK W.M., 2003, Management in Spatial ECONOMY, Publishing House Branta, BydgoszczPOZNAŃ (in Polish)

Goetgeluk R., Kauko T., PRIEMus H., 2005, Can Red Pay for Blue? Methods to Estimate the Added Value of Water in Residential Environments, Journal of Environmental Management and Planning, 48 (1), pp. 103-120.

GrANT J.L., 2009, Theory and Practice in Planning the Suburbs: Challenges to Implementing New Urbanism, Smart Growth, and Sustainability Principles, Planning Theory and Practice, 10 (1), pp. 11-33.

GROSS M., ŹRÓBEK R., (2013), "Public real estate management in post-socialist countries", Real Estate Management and Valuation, vol. 21, no. 4, pp. 11-16.

GulÁcsy E., PINTÉR L., PERRY J., 2006, The Tisza/Tisa Transboundary Environmental Disaster: An Opportunity for Institutional Learning [In:] The Environment and Sustainable Development in the New Central Europe, ed. Bochniarz Z., Cohen G.B., New York and Oxford: Berghahn Books, pp. 129-142.

Hegedüs J., MARK K., StruyK R., TOSICS I., 1994, Tenant Satisfaction with Public Housing Management: Budapest in Transition, Housing Studies, 9 (3), pp. 315-328.

JONES P., EVANS J., 2013, Urban regeneration in the UK. London [etc.]: SAGE.

Joss S., 2011, Eco-cities: The mainstreaming of urban sustainability - key characteristics and driving factors, International Journal of Sustainable Development Planning, 6 (3), pp. 268-285.

KAUKO T., 2013, Self-organizing map algorithms to identify sustainable neighbourhoods with an exaple of Szeged (Hungary), GIS Ostrava 2013 - Geoinformatics for City Transformation, January 21 - 23, 2013, Ostrava. Copy available at http://www.ntnu.no/documents/10443/f099a5f5-1a5a-4d18a63a-fbec62c953b3, access 17.02.2013.

KOVÁCs Z., 1998, Ghettoization or gentrification? Post-socialist scenarios for Budapest, Netherlands Journal of Housing and the Built Environment, 13 (1), pp. 63-82.

LADÁNYI J., 1993, Patterns of Residdential Segregation and the Gypsy Minority in Budapest, International Journal of Urban and Regional Research, 17 (1), pp. 30-41.

LARSEN K., 2005, New Urbanism's Role in Inner-city Neighbourhood Revitalization, Housing Studies, 20 (5), pp. 795-813. 
MAnZi T., LuCAS K., Lloyd-Jones T., Allen J., (Ed.), 2010a, Social Sustainability in Urban Areas. Communities, Connectivity and the Urban Fabric, Earthscan, London and Washington D.C.

MANZI T., LuCAS K., LlOYD-JONES T., AlLEN J., 2010b, Understanding Social Sustainability: Key Concepts and Developments in Theory and Practice, [In:] Social Sustainability in Urban Areas, Ed.: MANZI T., LUCAS K., LLOYD-JONES T., ALLEN J., Earthscan, London and Washington D.C., pp. 1-28.

MEŽ̌ICKÝ V., 2006, The Czech Republic: From Environmental Crisis to Sustainability, [In:] The Environment and Sustainable Development in the New Central Europe, Ed.: BOCHNIARZ Z., COHEN G.B., New York and Oxford: Berghahn Books, pp. 121-128.

MorRow-JONES H.A., IRWIN E.G., ROE B., 2004, Consumer Preference for Neotraditional Neighbourhood Characteristics, Housing Policy Debate, 15 (1), pp. 171-202.

Munasinghe M., 2010, Can Sustainable Consumers and Producers Save the Planet, Journal of Industrial Ecology, 14 (1), pp. 4-6.

Pessina G., ScAVUZZO L., 2010, From Crisis to Innovation: Searching for the Roots of the Sustainable Development of Vienna, EURA Conference, 24-26 September, Darmstadt, Germany.

PotTer R., Conway D., Evans R., Lloyd-Evans S., 2012, Key Concepts in Development Geography, Sage, Los Angeles, London etc.

Silhankova V., Koutny J., Mastalka M., Pondelicek M., Pavlas M., Kucerova Z., Vadurova J., VADURA ZD., 2011, Indicators of Sustainable Development for Municipalities, Hradec Králové: Civitas per Populi 2011.

SONG Y., KNAAP G.-J., 2003, New urbanism and housing values: a disaggregate assessment, Journal of Urban Economics, 54, pp. 218-238.

STØА E., 2009, Housing in the sustainable city - issues for an integrated approach, [In:] Urban Sustainability and Governance, Ed.: HOLT-JenSEN A., POLLOCK E., pp. 31-48.

TALEN E., 2011, Sprawl retrofit: sustainable urban form in unsustainable places, Environment and Planning B, 38, pp. 952-978.

VAishar A., GreEn-WoOTTEN B., 2006, Sustainable Development in Moravia: An Interpretation of the Role of the Small-Town Sector in Transitional Socioeconomic Evolution, [In:] The Environment and Sustainable Development in the New Central Europe, Ed.: BochNiARZ Z., COHEN G.B., New York and Oxford: Berghahn Books, pp. 121-128.

VÁSÁRHELY J., 2006, Building Local Sustainability in Hungary: Cross-Generational education and Community Participation in the Dörögd Basin. [In:] The Environment and Sustainable Development in the New Central Europe, Ed.: BochniARZ Z., COHEN G.B., New York and Oxford: Berghahn Books, pp. 232245.

WALLNER H.P., NARODOSLAWSKY M., MOSER F., 1996, Islands of sustainability: a bottom-op approach.

ZuindeAu B., 2006, Spatial Approach to Sustainable Development: Challenges of Equity and Efficacy, Regional Studies, 40 (5), pp. 459-470.

WOJEWNIK-FILIPKOWSKA A ,Public private cooperation in sustainable city development - the case study of public-private partnership in railway station area regeneration project.FIG Working Week 2012Knowing to manage the territory, protect the environment, evaluate the cultural heritage. Rome, Italy, 6-10 May 2012 www.fig.net/.../fig.../fig2012/.../TS05D_wojewnikfili

ŹRÓBEK-RÓŻAŃSKA A., ŹRÓBEK S., ŹRÓBEK R., 2014' Some problems of land use on the fringe areas of towns under urban sprawl pressure, http.enviro.vgt.lt, access 16.02.2015.

ŹRÓBEK S., ZACHAŚ M., 2005, The analysis of conflicts concerning urban area use: A case of Olsztyn (Poland), International Journal of Strategic Property Management 9, ISSN 1648-715X: 233-246.

\section{Other sources}

HICKS C., SPREAD Sustainable Lifestyles 2050, and UNEP/Wuppertal Institute Collaborating Centre on Sustainable Consumption and Production (CSCP). Speaker at the $3^{\text {rd }}$ Bonn Conference on International Development Policy 30-31 January, 2012: http://www.bonnconference.nrw.de/bonn-co_english/Speakers/index.php

MunASINGHE M., Chairman, Munasinghe Institute for Development (MIND), Colombo, Sri Lanka and Professor of Sustainable Development, Univ. of Manchester, United Kingdom. Speaker at the $3^{\text {rd }}$ Bonn Conference on International Development Policy 30-31 January, 2012: http://www.bonnconference.nrw.de/bonn-co_english/Speakers/index.php 